\title{
Construction and Practice of Collaborative Teaching Model for AES-based English Writing
}

\author{
Weiwei Qu \\ Teaching and Research Institute of Foreign Languages, Bohai University, Jinzhou, 121013, China \\ syquwei@yeah.net
}

Keywords: college English; writing teaching mode; construction and practice; cooperative learning; automated essay scoring (AES)

\begin{abstract}
Writing occupies very important position in college English teaching, which is a difficult problem of college English teaching as well, for a long time limits the overall improve the level of college English teaching. In this paper, based on the automated essay scoring research and collaborative learning mode, in order to promote college English teaching reform and improve the students' English writing level. First of all, the paper analyzes the problems existing in the teaching of college English writing. Then, this paper discusses the necessity of automated essay scoring apply in college English writing teaching. Finally, build the automated essay scoring applied to college English writing teaching mode automatically. The research achievements of this paper, provides a new model for college English teaching, to improve the English writing ability will play a positive role.
\end{abstract}

\section{Introduction}

English writing teaching has been the weak link of college English teaching in China. The needs of the international efficiency and the economic and social development, contemporary college students' English writing ability needs to be improved. The present state of teaching of English writing is that students think English writing is difficult, for writing has the fear; Teachers think that teaching effect is not good, take a lot of energy to explain, students level is not obvious, especially the thesis revises become a difficult problem. Corrects as students more, composition correcting quantity is big, cycle is long, makes the students' English writing opportunities to reduce accordingly, which in turn restricts the improvement of students' writing level. In this context, the automatic writing online evaluation system was born, reduce the burden of work of the teacher reviews, increases the chances of students' English writing, get the favors of the masses of teachers and students [1].

Writing the development of the automated essay scoring originated in the United States in the last century $60 \mathrm{~s}, 90 \mathrm{~s}$ of the development stage and the stage of development at the turn of the century. Started as a scoring mechanism, development purpose is mainly used for large-scale test scores, to at the beginning of this century, as the system function expansion, gradually applied to the course of formative assessment. Automated essay scoring applied in the teaching of writing, in addition to including the score function, include to the thesis provide written feedback, writing repository, teachers review and learning process management, and other functions. Based on researches on the automated essay scoring, this paper offers a new model for college English writing teaching and methods, to promote the college English teaching reform and improve the students' English writing level.

\section{Cooperative Learning Mode}

Collaborative learning is a structured and systematic learning strategy, students in order to complete the common task and a clear division of responsibility mutual learning. Cooperative learning encourages students to the interests of the collective and personal interests to learn together, in the process of a common task achieve their ideal. Collaborative learning is the beginning of $1970 \mathrm{~s}$ in the United States, and in the mid - 70 - s to mid - 80 - substantial progress was made in a creative 
and effective teaching theory and strategy. In improving the social psychological atmosphere of the classroom, and greatly improve student achievement, promote students to form good non-cognitive quality outstanding results, quickly attracted the attention of the world, and become one of the mainstream of contemporary teaching theory and strategy, has been praised as the most important and most successful in last decade of the teaching reform. Since the late $1980 \mathrm{~s}$, China have appeared in the collaborative learning research and experiment, and good results have been got $[2,3]$.

Modern teaching theory, cooperative learning can provide students with not only the comprehensive content and open forms of activity, but also can make the students to explore the outside world and at the same time, learn to communicate with people, form a friendship, make the students learn from each other, take others a long time, has been short. Constructivist teaching theory thinks, the student is in its own way to construct the understanding of things, because of the special experience and cultural background of the student's understanding of things are different, and collaborative learning can make students to see the different sides of problems, reflect on themselves and the views of others or criticism, so as to construct a new and updated level of understanding, at the same time, also enhanced the team spirit and cooperation consciousness. In the process of study and communication, often based on the experiment, the need of the comprehensive investigation and discussion, debate and opinion, require students to take the form of cooperative learning. Therefore, we need cooperation to explore, cooperate to explore a more active. Collaborative learning process is shown in Fig. 1.

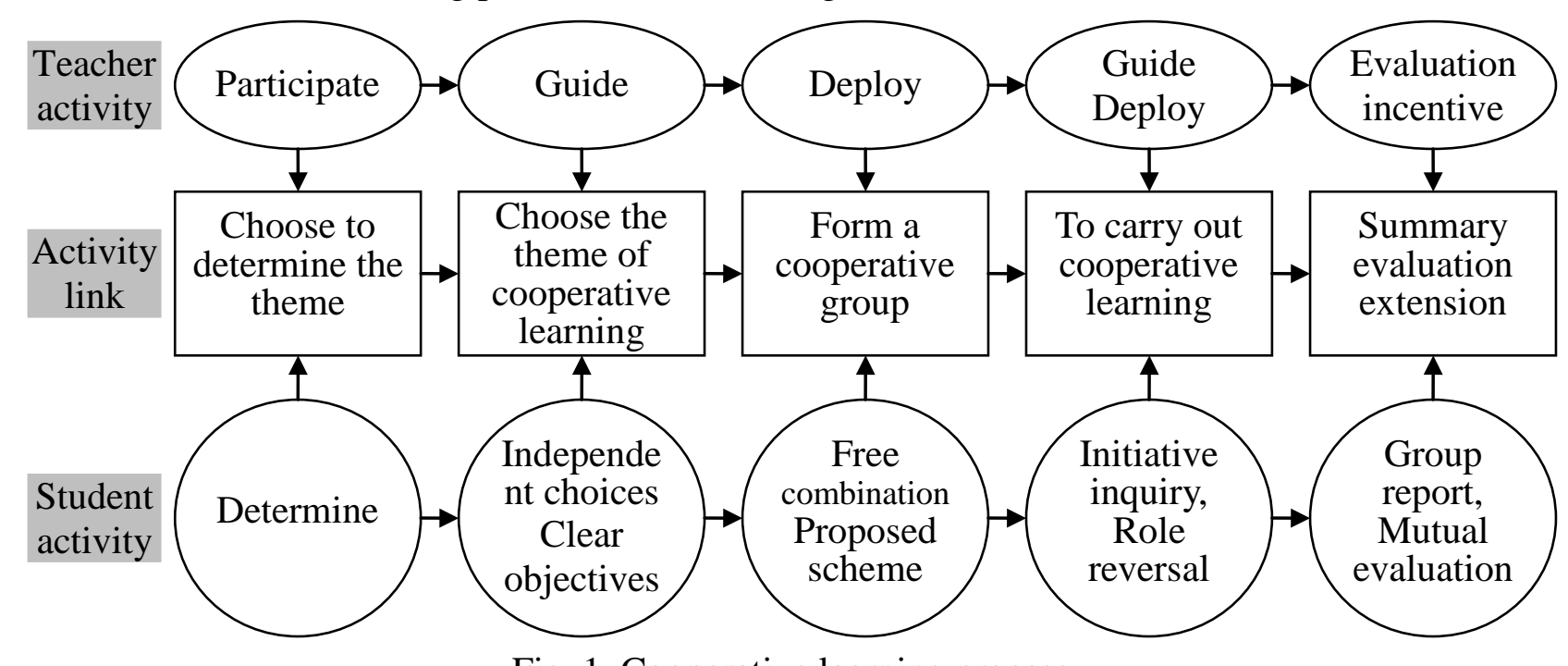

Fig. 1. Cooperative learning process

\section{Existing Problems on College English Writing Teaching}

The traditional pattern of college English writing teaching is that teachers import topics, writing materials are given, and step on; Corrects students imitate writing, the last teacher evaluation. The teaching process is shown in Fig. 2.

The problem of this writing teaching model:

(1) The students lack of knowledge, or don't have enough time to get the composition related scenario occurs in mind; The lack of communication and discussion between the classmate, not form a strict logical thinking; A lack of observation and thinking, there is no clear point of view. Often be patchy, the vocabulary of words commonly used is simple and insurance, write often is not a clear theme, thinking is not clear, all talk [4].

(2) It only be submitted to the teacher after completion of the whole piece, can't timely find problems in writing; The teacher cannot master the students' writing dynamic and periodic achievements; Students just according to their own memory and understanding in his writing, for 
some unknown words or syntax only with the help of online dictionary, not give full play to the important role of network resource and corpus.

(3) For a theme, writing in your native language can express it very perfect, if use English will express difficultly caused by the level of reason, resulting in language anxiety. In daily classroom teaching, the students rush to complete the work due to its improper teaching methods, students in a deal with the psychological, it is hard to stimulate students interest in writing.

\begin{tabular}{|c|c|c|c|c|c|c|c|}
\hline $\begin{array}{l}\text { Import } \\
\text { topic }\end{array}$ & $\begin{array}{c}\text { Sentence } \\
\text { expand }\end{array}$ & \multicolumn{2}{|c|}{$\begin{array}{l}\text { Task } \\
\text { present }\end{array}$} & \multicolumn{2}{|c|}{$\begin{array}{l}\text { Timed } \\
\text { writing }\end{array}$} & \begin{tabular}{|c|} 
Teacher \\
evaluation
\end{tabular} & $\begin{array}{l}\text { Work } \\
\text { modify }\end{array}$ \\
\hline$\downarrow$ & $\downarrow$ & $\nabla$ & $\nabla$ & $\nabla$ & $\neg$ & $\downarrow$ & $\downarrow$ \\
\hline $\begin{array}{c}\text { Topic } \\
\text { discussion, } \\
\text { Review } \\
\text { materials, } \\
\text { Organizat } \\
\text { ional } \\
\text { vocabulary }\end{array}$ & \begin{tabular}{|c|} 
Group \\
discussion, \\
Writing \\
ideas
\end{tabular} & $\begin{array}{l}\text { Design } \\
\text { writing } \\
\text { tasks, } \\
\text { point out } \\
\text { the main } \\
\text { points of } \\
\text { writing }\end{array}$ & $\begin{array}{c}\text { Great } \\
\text { writing } \\
\text { skills, } \\
\text { refined } \\
\text { writing } \\
\text { outline }\end{array}$ & $\begin{array}{c}\text { Tissue } \\
\text { material } \\
\text {, Draft } \\
\text { writing }\end{array}$ & $\begin{array}{l}\text { Modify, } \\
\text { Perfect } \\
\text { and } \\
\text { improve }\end{array}$ & $\begin{array}{c}\text { Teacher } \\
\text { correction } \\
\text {, give the } \\
\text { evaluation } \\
\text { results }\end{array}$ & $\begin{array}{c}\text { According } \\
\text { to the } \\
\text { teacher's } \\
\text { assessment } \\
\text { and } \\
\text { evaluation } \\
\text { results, } \\
\text { modify } \\
\text { the work }\end{array}$ \\
\hline
\end{tabular}

Fig. 2. Teaching process of college English writing

\section{Necessity on College English Writing Teaching based on Automated essay scoring}

With the development of economic globalization and international exchanges of extensive, and the development of information and network technology, use English to communicate, especially written English is more and more important. In English teaching at all levels in China, the teacher correcting a composition burden is heavy, works hard to ensure that every student can get timely and effective feedback. Because writing training volume is not enough, lead to a slow increase in the students' writing level. Due to factors such as teaching method, students' autonomous learning ability is generally weak, and the students' autonomous learning ability training of college English curriculum standard explicitly provided an important goal. So use based on modern information technology, and probes into the writing formative assessment tool to stimulate students enthusiasm, train the ability of autonomous learning, to improve students' writing level is the objective demand of the college English teaching.

According to the cognitivism writing perspective, English writing is a conscious process, usually including preparation stage, the pen and review corrections, and asked the author think positive all the time. Based on intervention, automatic marking system can make the whole process of writing in the classroom teaching, give full play to the enthusiasm of students, make writing three stages is repeated, so as to improve students English level in the process of writing. This with the relevant theory of second language acquisition "second language acquisition requires enough language output, know yourself in the process of output gaps" is the same. Word processing system and network provides a practice writing learning and discusses modification platform, students can easily modify repeatedly work, pay attention to the writing process, make the language input and output are dramatically increased, to improve English writing power of expression [5].

The traditional teaching mode gives priority to students write a composition and teachers correcting a composition mainly. In this process, the role of students is passive, the independent learning ability is weak, the motivation in revises the thesis is low, even more can't participate in the evaluation. Through the construction of teachers, students and system of evaluation and feedback mechanism, made it possible to writing process of interaction, the teacher feedback and peer feedback and the combination of feedback system, guarantee the timeliness of feedback and targeted, arouse the enthusiasm of the students' writing and editing, autonomous learning ability was improved. These changes directly with the change of the role of teachers and students, teachers from the traditional one and only evaluators and addressed to guide students to learn and supporters, 
problem solvers and evaluation of the participants, students from passive learners into active learners. Guided by teachers and system help, understanding and using to the students to participate in the evaluation standard, to participate in evaluation and self-evaluation, peer mutual, others grow into the study master, with the improvement of teaching efficiency.

\section{Mode Construction on College English Writing Teaching based on Automated essay scoring}

Construction is a term borrowed from the architectonics and the original refers to building up a kind of structure. Mainly used in cultural studies, social sciences and on the analysis of literary criticism. In cultural studies, social science and the use of literary criticism, a construction is to point to in the existing text, building up a system analysis and reading, so people can use a parsing context, to dismantling the reasons behind and ideology in the text. Teaching mode is in a certain teaching ideas or under the guidance of teaching theory, to achieve the teaching goal of the specific and set up a relatively stable teaching activity structure framework and activity program. Build a new teaching mode is the necessity of implementing quality education and curriculum reform goal request, build a new teaching mode is the inevitable requirement of curriculum reform development stage characteristics, build a new teaching model school teacher of the path to success. Aiming at the existing problems of college English writing teaching, give full play to the characteristics of collaborative teaching mode, the automated essay scoring of college English writing teaching process is shown in Fig. 3.

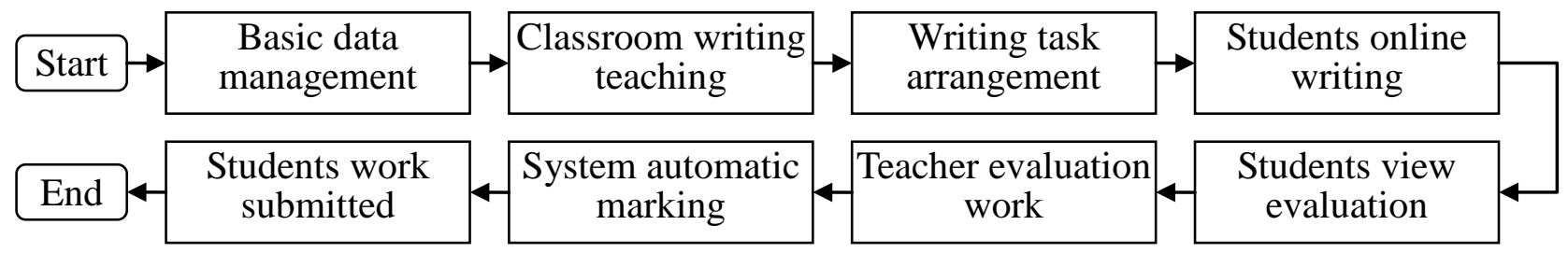

Fig. 3. Automated essay scoring applied to the teaching process of English writing

(1) Basic data management, Basic data management, Basic data used to support the system running, including student information, teacher information, course information, corpus and evaluation criteria and related data dictionary information, Basic data management is the information such as add, update, and delete operations. The operation according to the permissions can be done by the system administrator, and teacher.

(2) The classroom writing teaching Classroom writing would. Used to improve the students' writing level and integrated use of English, learn to express the integrity of the content, the writing coherence and the accuracy of the phrasing. Clear the requirement of the written expression, learn to complete the topic within the given time, determine the style, grasp ideas, language and writing revise skills and a series of work.

(3) The writing task arrangement, is closely connected with Writing anxiety and task arrangement, improper task decorate difficulty will reduce the quality of the Writing task [6]. Teachers should understand the students' writing psychology, understand the causes of anxiety, according to the students' knowledge level and psychological characteristics, constantly adjust the teaching methods, reasonable arrangement of writing tasks, to help students overcome anxiety, reduce the learning load.

(4) Students writing online Students online writing. The writing online is a direct way of writing on a network. In the process of writing, students can query the resource network to provide the corpus of dictionary, retrieval example sentences, phrases, or knowledge, can also differentiate synonyms [7]. Students writing content can be saved in time, avoid the local computer malfunction caused by writing content loss problem.

(5) The student work submitted. Students will work submitted to the Internet. Before the deadline, the student can be revised and resubmitted again and again. The system will record the student submit different versions of works, and submit date and time, every time the writing time 
and performance, etc. This functionality is similar to the configuration management in the process of software development, recorded the evolution process of student work.

(6) The system automatic marking. After students submit work, the System immediately to words, sentences, text structure and contents of the work related aspects carries on the analysis and give score; Give the inspection report, analysis of vocabulary from different dimensions, paragraphs, sentences, clauses and part of speech, such as types, providing measurements and reference range; Also pointed out that the existence of spelling, grammar, vocabulary and punctuation and collocation errors [8].

(7) The teacher evaluation work. The teachers' evaluation is more objective. Teachers can modify the student's work content, work give comments to the student, pointed out the advantages and problems of work, and work evaluation score is given. This functionality built a human-machine interactive platform, to give teachers a certain space, is a powerful supplement of the online evaluation system.

(8) Students view the evaluation. For each work, teachers and Students can view the system automatically evaluation result evaluation results. According to the result of evaluation, students can know their writing level, and the targeted modification work. Improve the level of writing through the evaluation results and it is the starting point of the use of automated essay scoring.

\section{Conclusion}

"College English curriculum requirements", points out that college English use a foreign language teaching theory as the instruction, in the English language knowledge and application skills, cross-cultural communication and learning strategy as the main content, and collect a variety of teaching modes and teaching means for the integration of teaching system [9]. In the process of teaching mainly develop the students' ability of listening comprehension, oral expression ability, reading comprehension, writing and translation ability. Among them, the written skills required to master basic skills of writing, can finish the general writing tasks, can describe personal experience, perception, emotion, and events, etc., can write common practical writing, the basic content integrity, central idea clearly, word, semantic coherence. The research achievements of this paper, provides a new model for college English teaching, to improve the written expression ability will play a positive role.

\section{Acknowledgement}

This work is supported by 2015 Cooperative project of Social Science Association of Liaoning province and Social Science Association of universities. (lslgslhl-025).

\section{References}

[1] Y. P. Wu, "Application research on Automated essay scoring for online writing in college English writing teaching," Theory and Practice of Contemporary Education, vol. 6, no. 11, pp. 100-102, 2014.

[2] Y. M. Li, "To promote English writing by group cooperative learning," College English (Academic Edition), vol. 12, no. 1, pp. 21-26, 2015.

[3] H. Y. Zhao, "The application of group cooperative learning in English teaching," English Square, vol. 5, no. 6, pp. 159-160, 2015.

[4] Q. J. Jiang, "A Study of the Application of Cooperative Learning Theory in College English Writing Teaching," Master's degree of Huazhong Normal University, 2012.

[5] Z. Q. Fu, "An empirical study on the application of online English writing automated essay scoring in English Writing Teaching," Journal of Mudanjiang College of Education, vol. 30, no. 4, pp. 114-115, 2012. 
[6] Pinzaijiu's blog, "On the arrangement of English writing anxiety and writing tasks," http://blog.sina.com.cn/s/blog_58acfbf601017k0m.html, 2016-4-27.

[7] W. T. Xu, "Research into the Cultivation of Big-data-driven English Online Writing Ability," Journal of Guangxi Normal University for Nationalities, vol. 33, no. 1, pp. 141-143, 2016.

[8] Y. Liu, "The application and effect of online writing evaluation system in the teaching of English Writing: A case study of the sentence "cool"," Overseas English, vol. 16, no. 5, pp. 80-82, 2015.

[9] G. D. Jia, "An Urgent Need of College English Teaching Reform in the New Time: On Revision of The College English Curriculum Requirements," Foreign Languages in China, vol. 9, no. 6, pp. 11-15, 2012. 